\title{
Effect of Mulch Materials and Nitrogen Source on the Performance of Tomato in the South-Western Coastal Area of Bangladesh ${ }^{\dagger}$
}

\author{
Md. Harunor Rashid 1, M. Akkas Ali 2,* and Mustafa Kamal Shahadat ${ }^{1}$ \\ 1 Bangladesh Agricultural Research Institute, On-Farm Research Division, Daulatpur, Khulna 9202, \\ Bangladesh; md_harunor_rashid@yahoo.com (M.H.R.); mustafa.shahadat@gmail.com (M.K.S.) \\ 2 Bangladesh Agricultural Research Institute, On-Farm Research Division, Joydebpur, \\ Gazipur 1701, Bangladesh \\ * Correspondence: akkasbari@gmail.com \\ + Presented at the Third International Tropical Agriculture Conference (TROPAG 2019), Brisbane, Australia, \\ 11-13 November 2019.
}

Published: 31 December 2019

\begin{abstract}
The major cropping pattern in the South-western coastal area of Bangladesh is transplanted aman rice followed by fallow during the rabi season (November to March) and kharif-I (April-July) season. Crop production during rabi season is limited due to various ecological factors including soil salinity, lack of fresh irrigation water, short winter period, late harvest of previous aman rice, heavy clay soil etc. Tomato is a popular winter crop in that area which is mainly cultivated around homestead and ridges of fish pond, where soil salinity and tillage is not a major problem. An attempt was taken to grow tomato in Khulna district of Bangladesh after T. Aman rice harvest during 2018-19 in order to investigate tomato performance at different mulch materials and Nitrogen sources. The two factors experiment was carried out in randomized complete block design with three replications. Mulch materials viz. rice straw $\left(\mathrm{M}_{1}\right)$, black polythene $\left(\mathrm{M}_{2}\right)$ and no mulch $\left(\mathrm{M}_{3}\right)$ were employed as factor one and nitrogen source viz. prilled urea $\left(\mathrm{N}_{1}\right)$ and urea super granule $\left(\mathrm{N}_{2}\right)$ were assigned as factor two. Results showed that there was no interaction effect of mulch and nitrogen treatments. Single effect of mulch and nitrogen treatments showed that highest fruit yield was found from rice straw $\left(\mathrm{M}_{1}\right)\left(17.32 \mathrm{t} \mathrm{ha}^{-1}\right)$ and prilled urea $\left(\mathrm{N}_{2}\right)\left(15.64 \mathrm{t} \mathrm{ha}^{-1}\right)$, respectively. So, tomato can be grown with rice straw mulch along with prilled urea for higher economic return (MBCR 2.24).
\end{abstract}

Keywords: tomato; mulch materials; source of nitrogen; yield

Funding: This research was jointly funded by Australian Centre for International Agricultural Research (ACIAR) (LWR/2014/073) and Krishi Gobeshona Foundation (KGF) (ICP I), Bangladesh.

Acknowledgments: We are thankful to Mohammad Mainuddin, Principal Research Scientist, CSIRO Land and Water, Australia and Richard Bell, Murdoch University, Australia for their valuable suggestions and encouragement.

Conflicts of Interest: The author declares no conflict of interest.

(C) 2019 by the authors. Licensee MDPI, Basel, Switzerland. This article is an open access article distributed under the terms and conditions of the Creative Commons Attribution (CC BY) license (http://creativecommons.org/licenses/by/4.0/). 